\author{
MARIA BARDYN, \\ Taras Shevchenko National University (Kyiv, Ukraine) \\ e-mail:marynet@ukr.net, ORCID0000-0002-0126-971X
}

\title{
APOCALYPTIC REFLECTIONS IN THE STUDIES OF THE RUSSIAN ORTHODOX PRIEST ALEXANDER MEN
}

The relevance of the article is due to the increased interest in the cultural heritage of the last century. The creative achievements and worldviews of priest Alexander Men, which are a significant component of the spiritual Russian culture, have been investigated. The works of Alexander are open to secular culture, science, to other faiths, non-Christian religions and deep church roots, they are accessible and simple for readers. Alexander Men did not create a special doctrine, because his main task was spiritual enlightenment and the exaltation of souls. Alexander Men was gifted not only with an analytical mind but also with a prophetic gift. Predictions about future are picked up by ignorant people and not only mislead them, but also become a source of distorted ideas about the Bible argued Alexander Men. First of all, Alexander Men in his researches seeks to answer the main questions that concern people, to reveal the very essence of the mysterious book of the Bible, to make its deep content not only a narrow circle of specialists, but also a wide reader. In the article a comprehensive analysis of the interpretation of the theologian's apocalyptic prophecies has been conducted. Alexander Men denies literal understanding of the Apocalypse images and emphasizes to allegorical character of this book. Numerous symbols, fantastic images and visions are revealed through the images of the prophetic books of the Old Testament. His initial thesis is to understand the Apocalypse as a permanent reality. Therefore, according to the theologian Alexander, apocalyptic prophecies are constantly being fulfilled and reproduced. The reasons for not accepting the apocalyptic reflections of Alexander Men by Orthodox priests have been defined: contradictory interpretations of Scripture, admiration for scientific facts, inclination for Catholicism, distortion of spiritual Orthodox practice, excessive liberalism, ecumenism, admiration for Western theology. However, Alexander Men played an important role in the Orthodox Church, he had many adherents (believers, priests, and researchers) and he is still mentioned in articles and conferences.

Key words: apocalyptic; orthodoxy; Christianity; theology; crisis; Bible; New Testament; prophecy.

Introduction

Apocalyptic issues were relevant throughout the development of Christian culture. In every historical era, apocalyptic prophecies were perceived in their own way.

An apocalyptic theme was very popular in the Orthodox Slavic countries during the middle Ages. Slavic manuscript tradition, almost all works of the Old Testament, early Christian and Byzantine apocalyptic was known in the oldworld. Most of them were translated into Slavic language in the XI-XIII centuries and existed in different versions with various alterations. It is considered that one of the variants of the apocryphal "Revelation of John" may have appeared on Slavic soil between the XI and XIII centuries.

This work describes the conversation of the Saint John the Apostle with Christ on the Mount of Olives, in which Christ talks about the future fate of the Jews, gentiles, infants, monks, etc.

In the New Age, apocalyptic themes were used in the literature of the Old Believers (staroobryadtsy).

It is known that in the end of the 19th and the first half of the 20th centuries were two main directions in the Orthodox theological and philosophical thought: academic theology and Russian religious philosophy.

Particular interest to the topic of apocalypse is found in the works of P. Florensky, A. Yelchaninov, V. Svientsytsky, M. Barsov, M. Glubokovsky, A. Orlov, M. Troitsky, S. Bulgakov.
Since the second half of the 19th century, the Orthodox Russian biblical science contributed to the study of John's Revelation. The first representative who devoted his work to this issue was Archimandrite Theodore (A. Bukharev), he tried to explain the course of the fate of the world and the Church. He understood Revelation as a prophetic image of human history. Further study of John's Revelation was conducted in a more academic way in Russia.

There was an active modernization of academic Orthodox theology at the beginning of the 20th century.

Bishop Cassian (Bezobrazov), Archbishop Averkia (Taushev) also considered the problem of Apocalypse in their works.

In the second half of the 20th century, some of the works dedicated to the Revelation of John were written in the USSR, but their publication in Russia became possible later.

Thus, in the academic tradition, the emphasis has gradually changed: from recognizing Revelation as an external authority, on the basis of which it is necessary to build a system of theology to substantiate the possibility of individual perception of Revelation by faith and reason.

The issue of Apocalypse is crucial for the theologians as people are always interested in the future. The works of the priest Alexander Men can be considered as a significant component of the spiritual culture of Russian society. 
Researchers' attention is mainly directed to his general worldviews, but there is no detailed and comprehensive analysis of the interpretation of the apocalyptic prophecies of Priest Alexander. It is necessary to comprehend the deep heritage of the priest Alexander Men, from his theological positions. Alexander Men, as a priest of the Orthodox Church, is a rather ambiguous figure; his works evoked both support and crushing criticism.

In foreign critical literature, it is necessary to single out the studies of T. Altitser "Russia and Apocalypse", D. Betsey "The Form of Apocalypse in New Russian Prose."

To find out the significance of the apocalyptic genre for Christian culture, we turned to authoritative researchers of the Christian tradition: N. llyin, E. Bartoshevich, A. Barashkov, V. Chetyrkin, A. Tkachenko, B. Maznitsky and others.

We studied Christian encyclopedias: Orthodox Encyclopedia, Biblical Encyclopedia, and The Bible's Comments on "The Revelation of St. John"

The objective is to show the features of understanding and interpretation of the apocalyptic prophecies of Alexander Men.

To achieve this goal, the following tasks are elaborated:

- identify features of the interpretation of apocalyptic literature in the Russian theological tradition;

- consider in detail the specifics of understanding and interpretation of Apocalypse in the work of Alexander Men;

- determine the significance of the work of Alexander

Men for the Orthodox Church;

- indicate the reasons for the critical attitude of Orthodox priests to the work of Alexander Men.

\section{Materials and Methods}

This work is based on the use of general scientific and special research methods. The main research approach was a systematic approach, a comparative historical method was also used, which made it possible to identify the main features, genesis and distribution of the Russian apocalyptic literary tradition in the Christian culture system, in comparing to the apocalyptic themes, motifs and images in the work of the Russian theologian. The hermeneutics method allowed interpreting the concepts in the work of Alexander Men.

\section{Results and Discussion}

Alexander Men (January 22, 1935 - September 9, 1990) was a priest of the Russian Orthodox Church, theologian, preacher, author of books on theology, history of Christianity and other religions. He deserved the love of liberalminded people and the hatred of enemies. As a result, Alexander Men was killed (Bychkov, 1996: 101). There is evidence that he sensed his impending death and felt an urgency about his ministry, speaking wherever possible about the Christian faith during the early years of perestroika (Men, 2014).

The Old Testament, pagan, inter-Testament and New Testament stories in the work of Alexander are distinguished by analytical power (Rashkovsky, 2018).

We would examine in more detail how the priest Alexander Men interpreted the last book of the New Testament "The Revelation of St. John".

On June 3, 1989, at the Gorky House of Culture, Alexander Men gave a lecture entitled "Apocalypse." The author noted that the Bible ended with the most mysterious, most formidable of the books of the New Testament, which had been imprinted in many works of world art and had been disturbing hearts of people for centuries, the believers, as well as the atheists ${ }^{1}$.

Men learned from quite a few importance of translating religion into ordinary language, revealing how the New Testament is about life, not just services in church (Plekon, 2017).

Men's work abruptly with his death and conditions in his Russia have changed dramatically. Nevertheless, there is a good reason to include him when reflection on the spiritual life in the everyday. In America, there was a surge of interest to Men in the late 1990s, with numerous translations of his writings, articles, and papers - there are also many conferences centers on his work. Men remains on the list important figures, but the is no longer the excitement as when he was first discovered and was being presented (Ibid).

According to Alexander Men, people turn to the theme of Apocalypse precisely at those moments when they feel helpless, deprived of God's grace - during various crisis moments of history. The attitude of people towards Apocalypse is not ambiguous: some with horror expect it to come, others are waiting for the finite coming of the law of God to our world, and everyone will receive what they deserve.

When the crisis came, people suddenly turned back to this ancient book of Apocalypse, in particular during the crisis of the Middle Ages, during the Renaissance and at the end of the 19th century.

In the context of our research, an article by A. Nebolsin turned out to be interesting. The author noted: "The Revelation of John is a book that has been interpreted throughout Christian history and using a variety of methods" (Nebolsin, 2010).

As a Christian thinker, Alexander Men was firmly rooted in the biblical theological tradition, in which universal spiritual meanings are expressed (Skorokhodova, 2011). Speaking about the perception of Apocalypse by Alexander Men, we need to remember two theses: firstly, he believes that Apocalypse is an issue that will always be relevant, since a person's life is imperfect; a person constantly commits sins, and accordingly is afraid of retribution. The book about Apocalypse is a work about the crisis of the entire human race, about the decline of culture, so it's completely logical to say that this topic is more relevant today than ever.

The second thesis of the priest is a special understanding and interpretation of Apocalypse. Alexander Men is sure that this is not only a combination of gloomy and terrible dystopias designed to keep a person in fear and obedience to a terrible end. Priest Alexander says that Apocalypse combines faith and hope, which, of course, might be considered absurd at the first glance.

"Reading Apocalypse" is a book of conversations of the priest Men, and nowadays this book is especially relevant. At all times, human strove to comprehend the past, realize the present, look into the future. (Men, 2000: 34 ). The author shows that the symbolic language of Revelation can be "transparent and understandable" to everyone, that many symbols, fantastic images and visions of Apocalypse are easily revealed through the images of the prophetic books of the Old Testament.

1 Біблія. Книги Святого Письма Старого та Нового Завіту [Bible. Books of the Holy Scriptures of the Old and New Testaments]. Kyiv: Ukrainian Bible Society, 2013 (In Ukrainian) 
"The Revelation of John" is the creation of a writer who does not participate in public life. And what is revealed to him can hardly be expressed in words. The apocalyptic is always figurative, it is associated with visions. Moreover, the apocalyptic portrays the future (Ibid: 27).

When Revelation was written and who was an author? These questions still remain open. The place of writing of Apocalypse is known from the book: it speaks of the island of Patmos. The dating of the book is still a moot point. Nevertheless, it was written no earlier than the beginning of the persecution under Nero's rule in 64 and no later than the reign of Domitian, that was in 95 year. Somewhere around this time a book was written. Alexander Men mentioned that it was significant that the book was written by the prophet John, one of the disciples of the Lord, under the inspiration of the Holy Spirit and recognized by the Church as an expression of our common faith, as the word of God.

In this regard, Priest Men concludes that these disputes about an author of Revelation are not important, as the book is devoted to the Revelation of Jesus Christ, not St. John. This is what Christ proclaims to people.

Due to these circumstances, the question of canonicity, sacredness, church authority of Apocalypse is urgent, and its canonicity has been disputed for centuries. Apocalypse in the church was never read during a liturgy, as the liturgical charter was established before the book finally entered to the biblical canon. As we know, the composition of the New Testament, particularly, an established list of works ("canon") was formed gradually. The official and final recognition of the 26 works (presented in the modern Bible) was made by Council of Laodicean (without Apocalypse) only in 363. In 419 Council of Carthage introduced Apocalypse into the canon. But the struggle around the problem of the truth of Apocalypse took place for a long time: the mandatory inclusion of it in the New Testament was confirmed at the Council of Constantinople in the 7 th century.

In "Revelation of St. John" we see pictures of history (meta-history) reproduced the essence of the historical process which is the struggle. Alexander Men develops his system of interpretation of symbolic images in Revelation. Alexander Men considers the glass sea as the symbol of the sky that can be interpreted as the transparent sea of the universe. Four animals on the edges indicate living creatures. Twenty-four elders around can be count as two to twelve are the founders of the Old Testament and the New Testament Church, to whom some secret of the world is revealed. The Lamb of God has an identity with Christ. The four horsemen of Apocalypse personify violence, war, hunger and death. This can be regarded a consequence of the fact that people seek material wealth and move away from the good and truth.

In Apocalypse, one after another, pictures of what is happening in the depths of history are displayed, for instance, a constant struggle of the good and evil, light and darkness. A monster, a Beast with a number 666 comes from the sea. In the ancient times, it was connected with Caesar Nero, who was an embodiment of despotism, murder, spiritual tyranny. Nevertheless, Alexander Men states that this does not mean that Apocalypse speaks of the past. In any era, every man of such spirit depicts an image of this beast. These are the consequences of the wrong development of mankind.

The following series of events come: there is another sign in the heaven - a woman who gives birth. A huge red dragon rises from the sea, and he is just waiting for a moment to devour this newborn baby. The red dragon is an ancient serpent, the one that seduces man in the Bible. This is the dragon of chaos. And now he becomes the dragon of the empire, the red color is the color of the imperial purple in Rome.

A woman is the Old Testament Church, which must give birth to a new spirit, give birth to Christ, the Messiah, and imperial Rome, is ready to devour it. Alexander Men interprets the image of a dragon and a woman in this way.

Apocalypse accompanies a constant struggle, all unclean forces drop their masks and everything becomes apparent. Archangel Michael fights against wickedness, against the triumphant ungodliness principle, the principle of Antichrist.

In the end, something else happens: the power of light paralyzes the forces of darkness, and as a result of the history we see: a partial victory of light and a partial victory of darkness. And both poles of the history continue to develop, periodically colliding in cataclysms.

The Book of Apocalypse is a warning to all of us that if humanity neglects the Covenant of God, it will suffer from fierce retribution. Consequently, a reason is not in God's punishment which is considered to be a primitive idea. On contrary, He created a moral world order, as a result of which evil would always ultimately be harmful. Retribution comes sooner or later. And good triumphs all the same. But a person must choose: with whom he is - with light or with darkness. This choice is relevant for us everywhere, namely in our private and public life.

Many people try to determine the time of Apocalypse. In fact, the end of the world is a permanent reality which is constantly reborn. Alexander Men notes: "Lord, does not come to judge the world, but to save it" (Men, 1991: 106).

Thus, Alexander Men notes the symbolic interpretation of the paintings of Apocalypse, where it is important to understand the meaning of the images. "Revelation" is a warning to humanity of keeping the Word of God. In addition, Apocalypse is a permanent reality. Therefore, humanity periodically experiences these apocalyptic prophecies. The judgment of God is ongoing and thus will continue in the future.

Of course, as for the Orthodox priest, such an understanding of the last book of the Bible is contradictory. That is why his work caused a lot of criticism from other Orthodox priests. Three main critics can be distinguished: Protodeacon Andrei Kuraev (2003: 360), Archpriest Sergiy Antiminsov and Priest Daniil Sysoev.

We can generically identify the issues that have been criticized:

1. The Problem of the Spirituality of Scripture. Sergiy Antiminsov and Danilo Sysoev argued that Alexander denied the blasphemy of Scripture, believing that the Bible was more a word and a work of a human than Divine. Alexander Men did not deny that the bases of biblical narratives were the true stories of God-inspired character, namely the revelation of the prophets. However, he believed the initial stories had "overgrown" with different fictions like folk fables.

2. There are doubts about a number of Bible miracles (this applies to both the Old and New Testaments).

3. Excessive fascination with biblical criticism and commentary from the Church Fathers.

4. Contradictory interpretations of the question of existence in the world of evil and the reasons for it. Antiminsov noted that, according to Alexander Men, "the perpetrator of world disorder was indirectly God, who allowed the divine forces of Chaos at the very beginning of the creation of the cosmos to distort world harmony" (Antiminsov, 1993). 
5. Some mistakes in the field of spiritual life.

Many critics had also accused Alexander Men of distorting the spiritual practice of Russian Orthodoxy.

6. Doubts about the divinity of Christ and, as a consequence, distortions in the field of Christology.

It is necessary to dwell more on the criticism of Alexander Men, in particular in the context of his understanding of apocalyptic prophecies, by Archpriest Sergius Antimisov (Ibid). It is interesting that Archpriest Sergei Antiminsov is just a pseudonym who has never dared to reveal himself. Thus, the author of the book notes that although Alexander Men is a priest of the Orthodox Church, in his writings there are many ideas and provisions that contradict the basic truths of the Orthodox faith. One reason for this, apparently, was that Alexander was heavily influenced by the non-Orthodox Western theology - Catholic and Protestant.

The priest tries to interpret the ambiguous prophecies of Christ about the end of the world history in the sense of a "permanent judgment". Allegedly, "the coming of the Son of God has truly been a judgment that goes on for ages. The new people of God will continually experience the "days of judgment" until the struggle of good and evil reaches the highest point of tension, and then the last judgment, fracture, breakthrough of history beyond its borders, purification and transformation of the world will take place" (Men, 1983: 243). "The judgment continues a new era is coming" (Ibid: 191).

Alexander Men wants to disguise of the main culprit of the world's evil - the devil. It brings together all manifestations of evil: the Chaos Monster, the serpent, the fallen spirit" (Men, 1996: 97).

It turns out that the apocalyptic dragon, the seducer of man in Eden, and the fallen spirit are different beings who "merged together" only in the last book of the Bible, and it is unclear whether they are individuals or beasts, as Alexander Men calls them a vague term "manifestations of evil".

In addition, an Antichrist of Alexander Men is a beast that contradicts the Orthodox beliefs. Apostle Paul clearly states that an Antichrist will be a man of sin, a son of perdition (2 Thess. 2: 3 ), who will not only establish his sole authority over the world (Revelation 17: 12-13), but will also demand worship for himself (2 Thess. 2: 4). He is also called a beast in Apocalypse (ch. 13) because of the ferocity of temper.

Sergei Antiminsov states that the task of the Orthodox priest according his faith is to explain that a sin is the main source of all evil. Moreover, this source is within each person. And only Christ can help in the fight against a sin. The only help is provided only through the Church which is the One, Holy, Council and Apostolic. The help is obtained through its sacraments, worship, traditions which are the experience of the Orthodox saints (Antiminsov, 1993).

The main drawback of Alexander Men's writings is that he "blurs" these clear and generally simple truths of the Orthodox doctrine of salvation. Alexander Men denies that Christ is the only Savior of humanity. Finally, it denies the reality of the formidable finale of human history - the Second Coming of Christ. Such distortion of the truths of the Orthodox faith throws believers into the arms of antiChristianity, which is far worse than pure atheism.

Errors in Alexander Men's work can be explained by many factors: excessive admiration for the Western theologians, Catholic and Protestant; lack of systematic theological education, enormous employment for parishes.

In contrast to these reproaches, there was the well- known pastoral good word of Metropolitan Anthony of Sourozh. There was the word of Kolomensky Juvenal, Archbishop of Vologda, Mikhail (Mudyugin), who said that the Church canonized Alexander Men over time at a radio station in St. Petersburg. Leonid Vasilenko was grateful to them that there were hierarchs who did not degrade the bishop (Vasilenko, 2000: 269).

Priest Georgy Chistyakov, on the 10th anniversary of the death of Alexander Men noted in his article: "Alexander was a priest and spiritual guide of thousands of believers, a writer and scholar, a tireless public figure and lecturer, a hard worker who worked without knowing the days off and rest, and died like a martyr - early Sunday morning on the way to the temple " (Chistyakov, 2000).

\section{Conclusion}

In accordance with the goals and objectives of the study, we came to the following conclusions:

Russian theological apocalyptic literature is a special genre of religious literature, the authors of which open the veil of the future destinies of the world to the reader in the form of a prophecy or a utopian scenario for the future.

The main themes of Russian theological apocalyptic literature were brought to Russia with the adoption of the Orthodoxy from the Byzantine apocalyptic, which was characterized by such motifs and plots as the special purpose of the Byzantine Empire and its emperors in recent times, as well as a motive of Antichrist.

Alexander Men explains in detail the hidden symbolism that lies in the apocalyptic prophecies. He denies a literal understanding of the paintings of Apocalypse and emphasizes their allegoric. In addition, the output of the issues is the understanding of apocalypse as a permanent reality. Thus, apocalyptic prophecies are constantly being fulfilled and reproduced.

Alexander Men caused controversial perception by the Orthodox priests. The reasons for the rejection of his work include: conflicting interpretations of the Holy Scriptures, ambiguity of scientific facts, and distortion of the spiritual Orthodox practice, excessive liberalism, ecumenism, and enthusiasm for the Western theology. Nevertheless, Alexander Men played an important role in the Orthodox Church, had many supporters (believers, priests, and researchers) and his name had mentioned in articles and conferences up to the present time.

\section{REFERENCES}

Antiminsov, S. (1993). O bogoslovii protoiereya Aleksandra Menya. Moscow: Pravilo very. Retrieved from http://krotov.info/ library/13_m/myen/de_antimins.html (Accessed 10.04.19) (In Russian)

Bychkov, S. S. (1996). Khronika neraskrytogo ubiystva. Moscow. Retrieved from https://imwerden.de/pdf/bychkovkhronika neraskrytogo ubijstva_1996 text.pdf (Accessed 12.06.2018). (In Russian)

Chistyakov, G. (2000). On truditsya sredi nas. Russkaya mysl. Retrieved from http://www.alexandrmen.com/pan.html (Accessed 17.08.19) (In Russian)

Kuraev, A. (2003). Vyzov ekumenizma. Moscow: Izdatelskiy Sovet Russkoy Pravoslavnoy Tserkvi, 384 p. (In Russian)

Men, A. (2014). An inner step toward God. Writings and teachings on prayer by Father Alexander Men. Brewster, Ma: Paraclete Press, $192 \mathrm{p}$.

Men, Aleksander. (1983). Syn Chelovecheskiy. Brussel, 490 p. (In Russian)

Men, Aleksander. (1991). Svet vo tme svetit. Moscow, AO "VITA-TSENTR". (In Russian) 
Men, Aleksander. (1996). Magiya. Okkultizm. Khristianstvo. Izdatelstvo: Fond im. Aleksandra Menya, 97p. (In Russian).

Men, Aleksander. (2000). Chitaya Apokalipsis. Moscow: Fond imeni Aleksandra Menya. (In Russian)

Nebolsin, A. S. (2010). Metody interpretatsii, eskhatologiya i struktura Otkroveniya loanna Bogoslova. Vestnik PSTGU. Seriya I. Issue 3 (31). (In Russian).

Plekon, M. (2017). The World As Sacrament: An Ecumenical Path Toward a Worldly Spirituality. Liturgical Press, Collegeville, MN, $272 \mathrm{p}$.

Rashkovsky, Eugenii B. (2018). From the Intellectual History of the XXth Century: Archpriest Alexander Men [Iz intellektualnodukhovnoy istorii KhKh stoletiya: protoierey Aleksandr Men (Zametki na polyakh knigi Uollesa Deniela)]. Voprosy Filosofii, 2: 153-161 (In Russian).

Skorokhodova, T. G. (2011). Vostokovednoe znachenie trudov A.V. Menya: indologicheskie aspekty. In: Vostok. Afro-Aziatskie obshchestva. Istoriya i sovremennost. Retrieved from http:// naukarus.com/vostokovednoe-znachenie-trudov-a-v-menyaindologicheskie-aspekty (In Russian).

Vasilenko, L. I. (2000). Posmertnaya travlya ottsa Aleksandra Menya. Vestnik Russkogo Khristianskogo Dvizheniya (ParizhNyu-York-Moskva), no180: 259-289. (In Russian)

\section{LIST OF REFERENCE LINKS}

Антиминсов С. О богословии протоиерея Александра Меня. Москва: Правило веры, 1993. URL: http://krotov.info/ library/13_m/myen/de_antimins.html (Дата звернення: 10.04.19)

Бычков С. С. Хроника нераскрытого убийства. Москва, 1996. URL: https://imwerden.de/pdf/bychkov_khronika_neraskrytogo_ubijstva_1996_text.pdf (дата звернення: 12.06.2018)
Василенко Л. И. Посмертная травля отца Александра Меня. Вестник Русского Христианского Движения (ПарижНью-Йорк-Москва), 2000, № 180, с. 259-289/

Кураев А. Вызов экуменизма. Изд. 2-е и доп. Москва: Издательский Совет Русской Православной Церкви, 2003. $384 \mathrm{c}$.

Мень А. Сын Человеческий. Брюссель, 1983. 490 с.

Мень А. Магия. Оккультизм. Христианство. Москва: Фонд им. Александра Меня,1996. 97с.

Мень А. Свет во тьме светит. М., АО "ВИТА-ЦЕНТР", 1991.

Мень. А. Читая Апокалипсис. Москва: Фонд имени Александра Меня, 2000.

Небольсин А.С. Методы интерпретации, эсхатология и структура Откровения Иоанна Богослова. Вестник ПСТГУ. Серия І. Вып. 3 (31). М., 2010.

Рашковский Е. Б. Из интеллектуально-духовной истории XX столетия: протоиерей Александр Мень (Заметки на полях книги Уоллеса Дэниела). Вопросы фрилософии. 2018. № 2. C. $153-161$.

Скороходова Т. Г. Востоковедное значение трудов А.В. Меня: индологические аспекты. Восток. Афрро-Азиатские общества. История и современность. 2011. URL: http:// naukarus.com/vostokovednoe-znachenie-trudov-a-v-menyaindologicheskie-aspekty (Дата звернення: 13.08.2019)

Чистяков Г. Он трудится среди нас. Русская мысль. 2000. URL: http://www.alexandrmen.com/pan.html (Дата звернення: 17.08.19)

Men A. An inner step toward God. Writings and teachings on prayer by Father Alexander Men / Edited by April French, translated by Christa Belyaeva. Brewster, Ma: Paraclete Press, 2014. 192 p.

Plekon M. The World As Sacrament: An Ecumenical Path Toward a Worldly Spirituality. Liturgical Press, Collegeville, MN, 2017. 272 p.

Марія Бардин,

Київський національний університет імені Тараса Шевченка (м. Київ, Украӥна)

e-mail: marynet@ukr.net, ORCID 0000-0002-0126-971X

\section{АПОКАЛІПТИЧНІ РЕФЛЕКСІЇ В ТВОРЧОСТІ РОСІЙСЬКОГО ПРАВОСЛАВНОГО СВЯЩЕННИКА ОЛЕКСАНДРА МЕНЯ}

Актуальність теми дослідження обумовлюється збільшеним на сьогоднішній день інтересом до культурної спадщини минулого сторіччя, де особливе значення, як і в наші дні, мали апокаліптичні пророцтва про кінець світу. Апокаліптична проблематика була актуальною протягом всього розвитку християнської культури, допомагаючи останній реалізовувати ключові ідеї про безсмертя, повернення втраченого раю, кінцеву перемогу добра над злом. У цьому відношенні спадщина о. О. Меня являє собою дуже значимий компонент духовної культури російського суспільства, яка потребує подальшого вивчення. Отець Олексадр Мень детально тлумачить і пояснює прихований символізм, закладений в апокаліптичних пророцтвах. Він заперечує буквальне розуміння картин Апокаліпсису і наголошує на їх алегоричності. Його вихідною тезою є розуміння Апокаліпсису, як перманентної реальності. Отже, на думку теолога, апокаліптичні пророцтва постійно здійснюються і відтворюються. Священник Олександр Мень викликав до себе неоднозначне та суперечливе ставлення 3 боку православних священників. Серед основних причин несприйняття його творчості дослідники виділяють: суперечливі інтерпретації Святого Письма, залучення наукових фактів до пояснення божественних проявів, схильність до католицтва, спотворення духовної православної практики, надмірний лібералізм, екуменізм, захоплення західним богослов'ям. Тим не менше, отець Олександр Мень відіграв важливу роль в православній церкві, він мав багатьох прихильників (як вірян, священників, так і дослідників) і до тепер його ім'я згадується в статях і конфесіях.

Ключові слова: апокаліптика; православ'я; християнство; богослов'я; криза; Біблія; Новий Завіт; пророцтва.

(c) Maria Bardyn

Надійшла до редакції: 26.08.2019

Прийнята до друку: 13.09.2019 